\title{
Hydro-biological assessment of Tumaria reservoir, Kashipur (Udham Singh Nagar)
}

\author{
Kumar Pramod and Shyam Radhe 厕
}

\begin{abstract}
The present study was under taken to assess the physico-chemical parameters and phytoplanktonic diversity of Tumaria reservoir Kashipur in the District Udham Singh Nagar, Uttarakhand, from January 2017 to December 2017. The quantitative analysis of physico-chemical parameter like temperature, $\mathrm{pH}$, transparency, velocity, total dissolved solids, dissolved oxygen; chloride, and qualitative analysis of three major groups of phytoplankton (Chlorophyceae, Bacilloriophyceae and Cyanophyceae) were studied. The aim of this study was to monitor the functioning of reservoir ecosystem and designed to monitor monthly variation in water quality parameter of Tumaria reservoir so as to assess its status and suitability. During this study it was found that all the selected physico-chemical parameters were within the prescribed limits for aquaculture. It was also found that Chlorophyceae (53\%) was the dominant over bacillariophyceae $\mathbf{2 6 \%}$ ) and cyanophyceae $\mathbf{( 2 1 \% )}$. Anthropogenic activities and monthly variation also assessed during study period.
\end{abstract}

Key words: Physico-chemical parameters, phytoplankton, Tumaria reservoir etc.

\section{Introduction}

Water is very important life supporting material. Every living organism needs water, without which neither the life nor any development is possible. Thus it is very much essential for a healthy growth. The Physico-chemical parameters also affect plankton distribution, sequential occurrence and species diversity (Jhingran, 1991). Kumar et al., (2014 a and b) Seasonal variation in physicochemical properties of Kali River in Pithoragarh district of Uttarakhand, India. Phytoplankton is the primary producers forming the first tropic level in the food chain. Phytoplankton diversity responds rapidly to changes in the aquatic environment particularly in relation to silica and other nutrients (Chellappan, 2008). Plankton is very sensitive to the environment they live in any change in the environment leads to the change in the plankton communities in term of tolerance, abundance, diversity and dominance in the habitat. Therefore, plankton population observation may be used as a reliable tool for bio monitoring studies to assess the pollution status of aquatic bodies (Davis, 1995;

\section{Author's Address}

Department of Zoology, R. H. G. (P.G.) College, Kashipur, U.S. Nagar, Uttarakhand

E-mail.: radhey.8088@gmail.com development a movement toward a color change, or a mechanical change in consistency. In this context, Mathivanan et al., 2008). Phytoplankton forms the vital source of energy in the fresh water environment. They initiate the fresh water food chain, by serving as food to primary consumers, which include zooplankton, shell fish and others (Tas et al., 2007).

The growing populations of cities and developing industry require ever greater quantities of water with each passing year. It is becoming increasingly more difficult to meet the growing consumption needs of water in large cities by means of underground waters and unregulated surface streams. Water reservoirs are very important tool for human beings since these reservoirs provide water for irrigation, hydropower, aquaculture and economy to the people. Tumaria extension dam in $1960-61$ by a revised project cost of Rs. 254.15 lacs and completed $10.00 \mathrm{Km}$ long in the year 1969-70 by expenditure of total Rs. 225.29 lacs. Also $230.80 \mathrm{Km}$ long canal system for irrigation and $4.100 \mathrm{~km}$ long Phika Feeder were constructed to feed this reservoir by diversion of Phika river at Phika Barrage having 07 nos.of other bays and 03 nos. under sluice that are designed for a discharge 
of 524cumecs . Total catchment area of Tumaria and Tumaria Ext.reservoir is 399.36 sq. $\mathrm{km}$. and total reservoir capacity of both dam at full reservoir level is $151.143 \mathrm{Mm}$ Tumaria reservoir is located in the district of Udham Singh Nagar, Uttarakhand. This study is conducted to find out the plankton diversity and physic-chemical parameters of Tumaria dam.

\section{Material and Methods}

Water quality parameter: The study was carried out by systematic collection of water samples from Tumaria reservoir.

1. Physico-chemical Parameters

2. Temperature

3. Velocity

4. $\mathrm{pH}$

5. Transparency

6. Total Dissolved Solids (TDS)

7. Dissolved Oxygen (DO)

8. Chlorides.

The samples were collected from the reservoir at a depth of one feet using polythene bottle of two litter capacity for period of six months (Jan 2017 to December 2017) at monthly. $\mathrm{pH}$ was measured on the spot using operated $\mathrm{pH}$ meter and temperature was measured with the help of simple, mercury filled Celsius thermometer having the accuracy of 0.1 and range $\mathrm{OOC}$ to $50 \mathrm{OC}$. The physico-chemical analysis was carried out the following method by Welch (1948), Trivedy and Goel (1986), standard methods of APHA (1995), Khanna and Bhutiani (2005) and Kumar (2009). The plankton samples for the present study were collected once in a Month from the sampling stations. The collections were made early in the morning by using the standard plankton net nylobolt (No.25) with $30 \mathrm{~cm}$ mouth diameter and length of $1 \mathrm{~m}$. The integrated samples were made by pooling the samples collected from sampling sites. In case of the river the samples across the river were collected from selecting points including the site. One hundred liter of water was filtered through plankton net for qualitative estimation of plankton. Samples were preserved in 5 per cent formalin. Then the samples were made up to $100 \mathrm{ml}$ and counting was done in a Sedgwick-Rafter cell (Welch, 1952, Edmonson
(1991). From this, the number of cells per liter was calculated and the per cent composition of various groups of phytoplankton were computed and graphically represented. Fresh water planktonic diatoms were collected using phytoplankton net (mesh size $20 \mu 1$ ) from sampling site.

\section{Results and Discussion}

The result of study are given below and also summarized in Table- 1 and Table- 2 .

Temperature: The value for individual observations for temperature of Tumaria reservoir ranged between $16.80^{\circ} \mathrm{C}-30.40^{\circ} \mathrm{C}$ for in the month of January and month of June, respectively, the lowest and highest value recorded. A more or less similar trend was observed by Bhutiani et al., 2018. pH: The value for individual observations for $\mathrm{pH}$ of Tumaria reservoir ranged between 7.0-7.9 for in the month of June and month of January, respectively, the lowest and highest value recorded. A more or less similar trend was observed by Khanna et al., 2014 and Bhutiani et al., 2018.

Velocity: The value for individual observations for velocity of Tumaria reservoir ranged between $0.15 \mathrm{~m} / \mathrm{s}-1.81 \mathrm{~m} / \mathrm{s}$ for in the month of October and month of July, respectively, the lowest and highest value recorded.

Total dissolved Solids (TDS): The value for individual observations for total dissolved solids of Tumaria reservoir ranged between $78.6 \mathrm{mg} / \mathrm{l}-240.6$ for in the month of February and month of July, respectively, the lowest and highest value recorded. A more or less similar trend was observed by Bhutiani et al., 2018.

DO: The value for individual observations for dissolved oxygen of Tumaria reservoir ranged between $6.0 \mathrm{mg} / \mathrm{l}-9.5 \mathrm{mg} / \mathrm{l}$ for in the month of June and month of Decemeber, respectively, the lowest and highest value recorded. A more or less similar trend was observed by Bhutiani et al., 2018.

Transparency: The value for individual observations for transparency of Tumaria reservoir ranged between $4.1 \mathrm{~cm}-12.2 \mathrm{~cm}$ for in the month of August and month of January, respectively, the lowest and highest value recorded.

Chlorides: The value for individual observations for chlorides of Tumaria reservoir ranged between $7.2 \mathrm{mg} / \mathrm{l}-23.5 \mathrm{mg} / \mathrm{l}$ for in the month of April and month of July, respectively, the lowest and highest 
value recorded. Temperature is an important abiotic factor in the aquatic ecosystem (Francis et al., 2007). The maximum temperature was recorded in month of June $30.4 \pm 0.5 \quad 0 \mathrm{C}$ and minimum temperature was recorded in month Jan $16.8 \pm 0.5$ 0C. Similar result with reference to the reservoir and river were shown by Hannan et al., 1979; Ruhela et al., 2017 and Harding (1992). Temp was positive correlated with velocity, TDS and chloride and negative correlated with $\mathrm{pH}, \mathrm{DO}$, and transparency. The maximum velocity was recorded in month of Jul $1.81 \pm 0.2 \mathrm{~m} / \mathrm{s}$ and minimum was recorded in month of $0.22 \pm 0.44 \mathrm{~m} / \mathrm{s}$. The maximum TDS was recorded in month of Jul $240.5 \pm 1.4 \mathrm{mg} / \mathrm{l}$ and minimum was recorded in month of Feb 78.6 \pm $1.5 \mathrm{mg} / \mathrm{l}$. TDS was positive correlated with temp., velocity, chloride and negative correlated with $\mathrm{pH}$ and transparency. The maximum $\mathrm{pH}$ was recorded in month of Jan7.9 \pm 0.8 and minimum was recorded in month of June $7.1 \pm 05$. The maximum DO was recorded in month of Dec. $9.5 \pm 0.5 \mathrm{mg} / \mathrm{l}$ and minimum was recorded in month Jul $6.2 \pm 0.5 \mathrm{mg} / \mathrm{l}$. DO was positive correlated with transp, $\mathrm{pH}$, and negative correlated with chlo., TDS, velocity, temp. The maximum Transp. was recorded in month Jan $12.02 \pm 05 \mathrm{~cm}$ and minimum was recorded in month of Aug. $4.1 \pm 0.5 \mathrm{~cm}$.

Table 1: Physico-Chemical parameters of Tumaria reservoir during January 2017 to December 2017

\begin{tabular}{|l|l|l|l|l|l|l|l|}
\hline $\begin{array}{l}\text { Parameter } \\
\text { IMonth }\end{array}$ & $\begin{array}{l}\text { Temp. } \\
\left({ }^{\mathbf{0}} \mathbf{C}\right)\end{array}$ & $\mathbf{p H}$ & $\begin{array}{l}\text { Velocity } \\
\mathbf{m} / \mathbf{s}\end{array}$ & $\begin{array}{l}\text { TDS } \\
(\mathbf{m g} / \mathbf{l})\end{array}$ & $\begin{array}{l}\mathbf{D O} \\
(\mathbf{m g} / \mathbf{l})\end{array}$ & $\begin{array}{l}\text { Trans. } \\
(\mathbf{c m})\end{array}$ & $\begin{array}{l}\text { Chlorides } \\
(\mathbf{m g} / \mathbf{l})\end{array}$ \\
\hline January & $16.8 \pm 0.5$ & $7.9 \pm 0.2$ & $0.69 \pm 0.2$ & $88.9 \pm 0.5$ & $8.4 \pm 0.5$ & $12.2 \pm 0.6$ & $9.3 \pm 0.6$ \\
\hline February & $18.5 \pm 0.9$ & $7.4 .6 \pm 0.4$ & $0.55 \pm 0.2$ & $78.6 \pm 0.4$ & $8.8 \pm 0.8$ & $17.2 \pm 0.5$ & $8.4 \pm 0.5$ \\
\hline March & $21.9 \pm 0.1$ & $7.5 \pm 0.5$ & $0.75 \pm 0.4$ & $89.5 \pm 0.5$ & $6.8 \pm 0.6$ & $8.5 \pm 0.6$ & $8.3 \pm 0.5$ \\
\hline April & $24.8 \pm 0.6$ & $7.5 \pm 0.5$ & $0.56 \pm 0.5$ & $91.3 \pm 0.4$ & $6.5 \pm 0.5$ & $6.9 \pm 0.5$ & $7.2 \pm 0.6$ \\
\hline May & $28.9 \pm 0.8$ & $7.3 \pm 0.5$ & $0.89 \pm 0.2$ & $91.8 \pm 0.5$ & $6.4 \pm 0.6$ & $5.6 \pm 0.3$ & $11.1 \pm 0.5$ \\
\hline June & $30.4 \pm 0.3$ & $7.0 \pm 0.8$ & $1.02 \pm 0.1$ & $98.5 \pm 0.3$ & $6.0 \pm 0.4$ & $5.6 \pm 0.5$ & $13.6 \pm 0.4$ \\
\hline July & $29.9 \pm 0.5$ & $7.2 \pm 0.6$ & $1.81 \pm 0.4$ & $240.5 \pm 0.9$ & $6.2 \pm 0.3$ & $4.8 \pm 0.6$ & $23.5 \pm 0.8$ \\
\hline August & $28.5 \pm 0.4$ & $7.12 \pm 0.5$ & $0.58 \pm 0.4$ & $125.2 \pm 1.2$ & $6.8 \pm 0.5$ & $4.1 \pm 0.5$ & $22.5 \pm 0.8$ \\
\hline September & $20.4 \pm 0.5$ & $7.3 \pm 0.5$ & $0.22 \pm 0.3$ & $105.2 \pm 0.8$ & $7.6 \pm 0.5$ & $6.8 \pm 0.4$ & $20.3 \pm 0.6$ \\
\hline October & $19.8 \pm 0.5$ & $7.5 \pm 0.4$ & $0.15 \pm 0.5$ & $105.1 \pm 0.9$ & $9.2 \pm 0.6$ & $6.5 \pm 0.4$ & $12.1 \pm 0.5$ \\
\hline November & $17.9 \pm 0.6$ & $7.7 \pm 0.6$ & $0.79 \pm 0.5$ & $98.5 \pm 0.5$ & $8.4 \pm 0.6$ & $8.8 \pm 0.6$ & $10.9 \pm 0.4$ \\
\hline December & $17.2 \pm 0.4$ & $7.7 \pm 0.4$ & $0.75 \pm 0.4$ & $88.6 \pm 0.8$ & $9.5 \pm 0.5$ & $10.5 \pm 0.3$ & $9.1 \pm 0.6$ \\
\hline
\end{tabular}

Table 2: List of Phytoplanktonic diversity of Tumaria reservoirs during Jan 2017 to Dec 2017

\begin{tabular}{|l|l|l|}
\hline Chlorophyceae & Bacillariophyceae & Cyanophyceae \\
\hline Volvox sp. & Fragilaria $s p$. & Anabaena $s p$. \\
\hline Chlamydomonas $s p$ & Bacillaria $s p$ & Nostoc sp. \\
\hline Oedogonium $s p$. & Nitzchia $s p$ & Spirulina $s p$. \\
\hline Euglena & Diatom sp. & Oscillatoria sp \\
\hline Closterium $s p$ & Cymbella sp. & \\
\hline Spirogyra sp. & & \\
\hline Pediastream & & \\
\hline Cladophora & & \\
\hline Comarium sp. & & \\
\hline Ankistrodesmus $s p$. & & \\
\hline
\end{tabular}




\section{Phytoplankton composition of Tumaria reservoir during Jan 2017-Dec-2017}

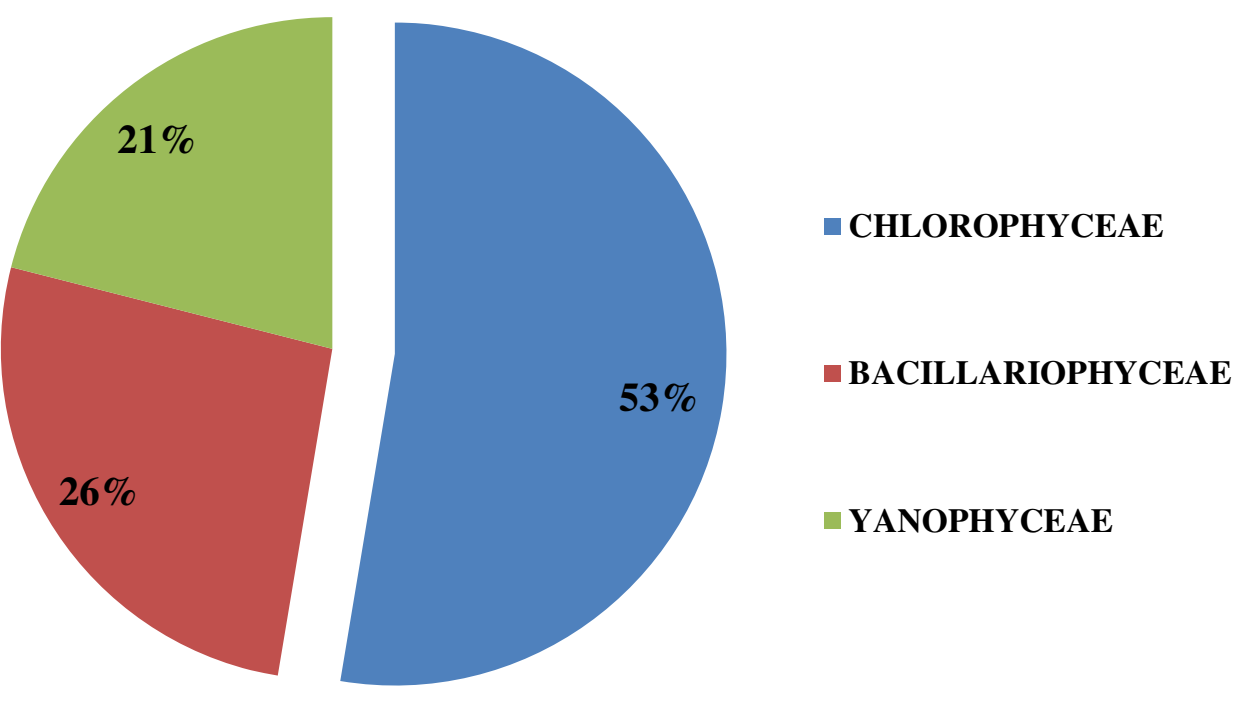

Fig 1: Showing the composition of Phytoplankton of Tumaria reservoir during Jan 2017 to Dec 2017

During the study Chlorophyceae $(53 \%)$ were for providing the basic laboratory facilities and recorded maximum among all groups of encouragement during this research work. phytoplankton, followed by Bacilloriophyceae (26\%) and Cynophyceae (21\%) throughout the year. Chlorophyceae was most dominant over the all species (Chlorophyceae >Bacilloriophyceae $>$ Cynophyceae) due to favorable environmental conditions (Khanna and Bhutiani, 2005; Kumawat and Jawale 2003; and Pawar et al., 2006).

\section{Conclusion}

The present study concluded that physico-chemical parameters indicate that good quality of water of the study area was not polluted with respect to physico-chemical assessment. Therefore this water can be useful to potable and drinking purpose.

\section{Acknowledgement}

\section{References}

APHA-AWWA-WPCS, 1998. The examination of water and waste water 20th Edition Washington DC.

Bhadula, S. and Joshi, B.D., 2012. Studies on Phytoplanktonic Diversity of River Ganga, Within Haridwar City, Uttarakhand. J. Environ. \& Bio. Sci.26 (1): 139-141.

Bhadula, S., Sharma, V. and Joshi, B.D., 2013. Impact of Touristic Activities on Water Quality of Sahashtradhara Stream, Dehradun. Int. Journal of Chem \& Tech.. 6 (1). 213-221.

Bhutiani, R., Khanna, D.R., Malik Rahul Ahamad Faheem and Tyagi Varun, 2018.Physico-Chemical characterization of River Ganga at Haridwar, Uttarakhand. Water biology, (ISBN-978-93-5056-888-0):143-159.

The authors are thankful to Head of Department Zoology, Kumaun University R.H. Govt. (P.G) College, Kashipur Uttarakhand India

Bhutiani R., Khanna, D.R., Ahamad Faheem and Tyagi Varun, 2018. Assessment of water quality stauts of Malin river at Najibabad, Bijnor (UP), Water biology, (ISBN-978-935056-888-0):281-307. 


\section{Hydro-biological assessment of Tumaria Reservoir}

Chellappan, N.T., Borba, J.M., and Rocha, O., 2008. Phytoplankton community and physicochemical characteristics of water in the public reservoir of cruzeta, R.N. Brazil. Braz. J. Biol.,68: 477-494.

Davis, T., 1995. The marine and fresh water plankton community constables and company limited London:539.

Edmondshon W. T. 1991 \& The uses or ecology: Lake Washington and beyond. Unlv. of Washington Press. Seattle.

Johnson, J.A. \& M. Arunachalam, 2009. Diversity, distribution and assemblage structure of fishes in streams of southern Western Ghats, India. Journal of Threatened Taxa 1(10): 507-513.

Johnson, J.A., Ramesh, R.K., Sen, S. and Sreenivasa, M. R., 2012. Fish diversity and assemblage structure in Ken River of Panna landscape, central India. Journal of Threatened Taxa. 4(13): 3161-3172.

Khanna and Bhutiani, 2005. Water analysis at glance, ASEA publication Rishikesh :1-115.

Khanna D.R., and Bhutiani R., 2005. Benthic fauna and its ecology of river Ganga from Rishikesh to Haridwar (Uttarakhand) India. Environment Conservation Journal 6(1):33-40

Khanna, D.R., 1993. Ecology and Pollution of Ganga River, Ashish publication house Delhi :1-241.I

Khanna, D.R., Bhutiani R., Tyagi Varun and Ahamad Faheem 2014. Impact of Sugar mill Effluent on Physico-chemical properties of Malin River in Najibabad. Indian J. Sci. Res. Spl. Ed. NSESIR :5-10

Kumar Pramod, Panday Anupama and Upadhyay Hem Chandra. 2014a. Seasonal variation in physico-chemical properties of Kali River in Pithoragarh district of Uttarakhand, India. J.Environ. Res. Develop. 8(3A): 600606

Kumar Pramod, Upadhyay Hem Chandra and Panday Anupama. 2014 b. Monthly variation in physico- chemical properties of Kosi River in Almora, District, UK. Environ. Cons. Journal, 15(1 and 2): 201-205.

Kumar, P., 2009. The impact of Tehri dam on aquatic ecologyof Bhagirathi River at Tehri Garhwal.Ph.D. Thesis,G.K.V. Haridwar.

Kumawat, D.A. and Jawale, A.K. (2003): Phytoplankters of a fish pond at Anjale, Maharashtra. Eco-Env. and Cons. 9 (3):411-415.

Pawar, B.A. and Mane, U.H., 2006. Hydrography of sadatpur lake near Pravaranagar, Ahmednagar district, Maharashtra. J. Aqua. Biol., 21 (1): 101-104.

Ruhela Mukesh, Bhutiani R., Ahamad Faheem, 2017. Pollution Status of River Hindon from Ghaziabad to Noida with Special Reference to Heavy Metals. International Journal of Advance Engineering and Research Development , 4( 8):540-548.

Tas, T., Beyhan, S., and Gonulol, A., 2007. An ecologic and taxonomic study on phytoplankton of a shallow lake, Turkey. J. Environ. Biol., 28:439-445.

Trivedy,R.K. and Goel,P.K.., 1984. Chemical and biological methods for water pollution studies, Environ, publication karad, Maharashtra India.

Wehch, T.S., 1952. Limnology (2nd edn.).New York: McGraw Hill Book Co.:538.

Welch, P.S., 1948. Limnology methods. McGraw-Hill book Co.Inc.montreal. 